\title{
Relative paleointensity of the geomagnetic field over the last 21,000 years BP from sediment cores, Lake El Trébol (Patagonia, Argentina)
}

\author{
C. S. G. Gogorza ${ }^{1,2}$, M. A. Irurzun ${ }^{1,2}$, M. A. E. Chaparro ${ }^{1,2}$, J. M. Lirio ${ }^{3}$, H. Nunez ${ }^{3}$, P. G. Bercoff ${ }^{2,4}$, and A. M. Sinito ${ }^{1,2}$ \\ ${ }^{1}$ IFAS- Universidad Nacional del Centro, Pinto 399, 7000 Tandil, Argentina \\ ${ }^{2}$ CONICET. Rivadavia 1917-1033 Buenos Aires, Argentina \\ ${ }^{3}$ Instituto Antártico Argentino - Cerrito 1248 - Buenos Aires, Argentina \\ ${ }^{4}$ Fac. de Matemática, Astronomía y Física, Universidad Nacional de Córdoba, Ob. Trejo 242, Córdoba, Argentina
}

(Received November 30, 2005; Revised May 5, 2006; Accepted May 8, 2006; Online published November 8, 2006)

\begin{abstract}
Four cores from Lake El Trébol (Patagonia, Argentina) have been used to estimate regional geomagnetic paleointensity. The rock magnetic studies indicate that the magnetic mineralogy of the clay-rich sediments is dominated by pseudo-single domain magnetite in a range of grain sizes and concentration which are suitable for paleointensity studies. The remanent magnetisation at $20 \mathrm{mT}\left(\mathrm{NRM}_{20 \mathrm{mT}}\right)$ has been normalised using the anhysteric remanent magnetisation at $20 \mathrm{mT}\left(\mathrm{ARM}_{20 \mathrm{mT}}\right)$, the saturation of the isothermal remanent magnetisation at $20 \mathrm{mT}\left(\mathrm{SIRM}_{20 \mathrm{mT}}\right)$ and the low field magnetic susceptibility $(k)$. Coherence function analysis indicates that the normalised records are free of environmental influences. Our paleointensity $\left(\mathrm{NRM}_{20 \mathrm{mT}} / \mathrm{ARM}_{20 \mathrm{mT}}\right)$ versus age curve shows good agreement with published record from another lake in Argentina and with records from other parts of the world, suggesting that, in suitable sediments, paleointensity of the geomagnetic field can give a globally coherent, dominantly dipolar signal.
\end{abstract}

Key words: Relative paleointensity, sediment cores, South America, Lake El Trébol, coherence.

\section{Introduction}

Sediments from lacustrine environments are frequently studied for directional and relative paleointensity variations of the geomagnetic field. They are attractive recorders of the geomagnetic field due to their continuity, high temporal resolution, and global availability. The conventional method of extracting geomagnetic field information from the signal consists in normalising the natural remanent magnetisation (NRM) with some normaliser. This normaliser should account for changes in magnetic grain size and concentration, which also affect the strength of the NRM signal. Different normalisers have been proposed, such as anhysteric remanent magnetisation (ARM), saturation isothermal remanent magnetisation (SIRM), and magnetic susceptibility $k$ (Tauxe, 1993). Similarity between normalised records obtained using different normalisers is often believed to express the reliability of the paleointensity record. Normalising the record is assumed to minimize the effects of magnetic grain-size distribution and variation of magnetic input, for example determined by environmental effects. Tauxe (1993) reviewed the experimental and theoretical considerations for assessing the reliability of paleointensity data derived from sediments. It is only possible to obtain relative paleointensity estimates from sediments in this way, in contrast to the absolute paleointensity determination from igneous rocks (Kruiver et al., 1999).

During the past decade, numerous studies have been

Copyright (c) The Society of Geomagnetism and Earth, Planetary and Space Sciences (SGEPSS); The Seismological Society of Japan; The Volcanological Society of Japan; The Geodetic Society of Japan; The Japanese Society for Planetary Sciences; TERRAPUB. made to recover the relative paleointensity from marine records. (e.g. Tric et al., 1992; Meynadier et al., 1992; Roberts et al., 1997; Channel et al., 2000; Laj et al., 2000; Sagnotti et al., 2001; Stoner et al., 2002). Comparatively, few studies have been made on terrestrial sediments, probably due to their more complex sedimentological characteristics (Peck et al., 1996; Sinito and Nuñez, 1997; Brachfeld and Banerjee, 2000; Nowaczyk et al., 2001; Pan et al., 2001; Brachfeld et al., 2003; St-Onge et al., 2003; Gogorza et al., 2004).

In this paper we present a paleointensity record obtained from four cores taken from Lake El Trébol (Patagonia, Argentina). First, we demonstrate that the sediments are suitable for paleointensity study by addressing the criteria of Banerjee et al. (1981), King et al. (1982, 1983), Tauxe (1993). We then develop stacked relative paleointensity records using conventional normalisation. The directional parameters corresponding to these cores have already been presented (Irurzun et al., 2006).

\section{Site Description}

Lake El Trébol, a closed basin $\left(41^{\circ} 04^{\prime} \mathrm{S} 71^{\circ} 29^{\prime} \mathrm{W}\right)$, is an oligotrophic, small lake (surface area: $0.4 \mathrm{~km}^{2}$, maximum depth $=11 \mathrm{~m}$ ), located at $758 \mathrm{~m}$ a.s.l. on the east side of the Andean Patagónica Cordillera, in a wooded area with moderate human influence (Fig. 1). At present, no perennial stream discharges into the lake and the hydrological budget is dominated by groundwater influx and losses by evaporation (Bianchi et al., 1999). The area is dominated by humid winds from the west with annual precipitation between 1500 and $1800 \mathrm{~mm} /$ year; the average annual temperature is 


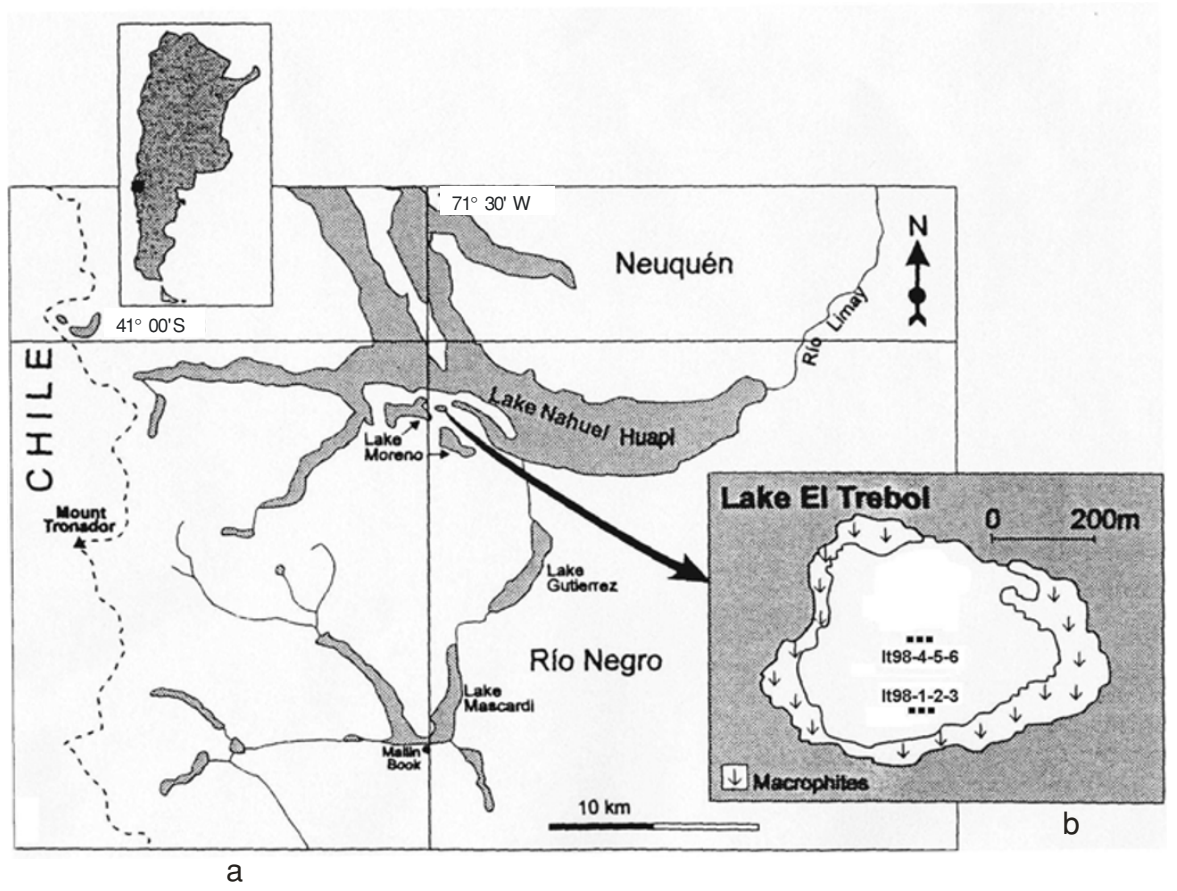

Fig. 1. (a) Geographical location of lake El Trébol. (b) Location of coring sites in the lake.

about $8.7^{\circ} \mathrm{C}$.

Advances and retreats of glaciers during the Pleistocene glaciation shaped the surrounding landscape. As a result, numerous glacial melt-water spillways, lakes (e.g. Lake El Trébol and Lake Escondido) and glacio-fluvial deposits were formed (Flint and Fidalgo, 1964, 1969; Rabassa and Clapperton, 1990; Bianchi et al., 1999).

\section{Sedimentology}

The basement rocks of the basin crop out on the lake coast. Basement exhibits evidence of glacial erosion, and some erratic blocks of different composition are present (Gogorza et al., 2002). The push corer reached the basement (or erratic blocks), going through a sedimentary column, that is represented by the cores (Irurzun et al., 2006). The four cores are sedimentologically similar and represent the most complete sedimentary record from El Trébol Lake to date.

The core labelled lt98-4 was chosen as a master core because it was the longest sedimentary column (figure 2 in Irurzun et al., 2006). Three principal lithologies are present in the sedimentary column, from bottom to top:

(A) It lies over the irregular surface of the Ventana Formation with glacial erosion evidence. The volcanic rocks of the Ventana Formation form the basement of Lake El Trébol and other small lakes in the area (Lake Escondido and Lake Moreno). Between 11.0 and $8.0 \mathrm{~m}$ depth, light reddish clayey silt, and very poor in organic matter content. This lithology shows fine parallel lamination composed by alternating thin layers of clastic varves. The individual layers are normally graded. The thickness varies from 1 up to $5 \mathrm{~mm}$ and the thicker layers, being in the middle part of the lithology A, suggest a probable local glacial advance. The grain size increases downward. Small dropstones were observed close to the bottom.
(B) Between 8.00 and $6.75 \mathrm{~m}$ depth, light grey clay, this lithology shows scarce lamination, especially near the upper section. This is a glaciolacustrine distal facies. The organic matter content, although poor, increases upwards.

(C) Between 6.75 and $0 \mathrm{~m}$ depth, core deep dark brown clay, lighter at the base, without lamination. It shows a relative increase of organic matter content in a lacustrine environment similar to that found in the present lakes.

Detailed visual descriptions of the cores along with rock magnetic studies allow the identification of two different facies in Lake El Trébol: a basal glaciolacustrine facies that includes lithologies A, B and tephra layers called "Lake Elpalafquen" facies, and a younger organic rich lacustrine facies (lithologies C and tephra layers) or "Lake El Trébol" facies (Irurzun et al., 2006).

Based on prior work in the region (del Valle et al., 2000) we interpret that lithologies A and B suggest the existence of a big lacustrine system, a paleolake Elpalafquen, with a level $100 \mathrm{~m}$ higher than the present Lake El Trébol. A system of glacial lakes contained by the receding glaciers remained during the climate improvement after the last glacial event. The disintegration of this glaciolacustrine system gave rise to many small ice-free lakes, like Lake El Trébol (del Valle et al., 1996).

\section{Experimental Methods}

A more detailed description of these items is given in Irurzun et al. (2006). A brief summary follows. The four cores investigated in this study (1t98-1, 1t98-2, 1t98-4, 1t985) were recovered at water depths of about $10 \mathrm{~m}$ from Lake El Trébol in 1998 using a push corer installed on a raft with a central hole. The cores of $6 \mathrm{~cm}$ diameter were recovered in $2 \mathrm{~m}$ long sections, with a common internal orientation, but were not orientated relative to magnetic north. The compaction is minimum. The sediments were extruded 


\begin{tabular}{ccccccc}
\multicolumn{7}{c}{ Table 1. $\delta^{13} \mathrm{C}$, radiocarbon and calibrated ages ${ }^{\mathrm{a}}}$. \\
\hline Core & Material & $\begin{array}{c}\text { Depth } \\
(\mathrm{cm})\end{array}$ & $\begin{array}{c}\text { Shortened } \\
\text { depth }(\mathrm{cm})\end{array}$ & $\begin{array}{c}\text { Date } \\
\text { RCYBP } \pm 2 \sigma\end{array}$ & $\begin{array}{c}\delta^{13} \mathrm{C}^{\mathrm{b}} \\
(\% o)\end{array}$ & $\begin{array}{c}\text { Calibrated } \\
\text { age } \pm 2 \sigma(\text { years })\end{array}$ \\
\hline 1t98-4 & sediment & 240 & 214.5 & $3206 \pm 42$ & -28.02 & $3464 \pm 98$ \\
lt98-4 & sediment & 439.5 & 363 & $7076 \pm 51$ & -25.974 & $7910 \pm 96$ \\
1t98-4 & sediment & 558.5 & 424 & $9886 \pm 54$ & -26.5 & $11007 \pm 316$ \\
\hline
\end{tabular}

a Irurzun, M. A., C. S. G. Gogorza, A. M. Sinito, J. M. Lirio, H. Nunez, M. A. E. Chaparro, Paleosecular variations recorded by sediments from Lake El Trébol, Argentina, Phys. Earth and Planet. Inter., 154, 1-17, 2006.

${ }^{\mathrm{b}}$ These $\delta^{13} \mathrm{C}$ measurements provide information to correct the ${ }^{14} \mathrm{C}$ ages to $\delta^{13} \mathrm{C}$ of $-250 / 00$.

using the included piston. There is no overlap between the $2 \mathrm{~m}$ long sections but they are extracted in a complementary way, so that no section were lost, i.e. if a section is missing in a core, it is present in another one. The position of the sampling sites and the main characteristics of the four cores are given in Fig. 1. These cores have been kept moist and refrigerated since they were collected, virtually eliminating the effect of core storage on the remanence.

One half of each core was subsampled with cubic plastic boxes of $8 \mathrm{~cm}^{3}$. In total, 1270 subsamples were obtained. Sub-sampling for rock magnetic studies and for ${ }^{14} \mathrm{C}$ and $\delta^{13} \mathrm{C}$ analysis was carried out.

The nature of the magnetic minerals in the studied sediments has been carefully investigated (Irurzun et al., 2006). The following measurements were performed for all samples: NRM; magnetic susceptibility at low frequency (specific, $X$ and volumetric, $k$ ); isothermal remanent magnetisation (IRM) in increasing steps up to $1.2 \mathrm{~T}$, reaching the SIRM; back field, in growing steps until cancelling the magnetic remanence; anhysteric remanent magnetisation $\left(\mathrm{ARM}_{100 \mathrm{mT}}\right)$, with a direct field of $0.1 \mathrm{mT}$ and a peak alternating field of $100 \mathrm{mT}$. Associated parameters calculated by Irurzun et al. (2006) were also used: Sratio $\left(\mathrm{IRM}_{-300 \mathrm{mT}} / \mathrm{SIRM}\right)$, remanent coercitive field $\left(\mathrm{H}_{\mathrm{CR}}\right)$, $\mathrm{SIRM} / k, \mathrm{ARM}_{100 \mathrm{mT}} / k$ and $\mathrm{SIRM} / \mathrm{ARM}_{100 \mathrm{mT}}$. In addition to these, hysteresis curves and temperature dependence of SIRM were obtained for a set of discrete samples.

The hysteresis parameters were obtained using a VSM Lake Shore 7300 with a maximum applied field of $1.5 \mathrm{~T}$. Thermal demagnetisation was made by a Thermal Specimen Demagnetiser, model TD-48 ASC Scientific. Stepwise thermal demagnetisation curves were represented and critical temperatures $\left(\mathrm{T}_{\mathrm{C}}\right)$ were estimated.

The depth scales of all the cores were adjusted to the depth scale of a chosen master core (1t98-4) using lithology and $X$ tie lines for correlation (Gogorza et al., 1999, 2001, 2002, 2004). One of the most important problems in lake sediments of a volcanic area is the presence of abundant tephra layers along the sequence. On the one hand, the tephra layers represent rapid instantaneous deposition of thick layers, whereas the rest of the sediments represent slow accumulation. On the other hand, tephra is not a very good magnetic recorder of directions (Peng and King, 1992; Gogorza et al., 1999). For these reasons, after the identification of the tephra layers, they were removed from the sequence and the gaps that were produced along the profiles by their removal were closed, obtaining a "shortened depth" scale. This method was described in detail by Gogorza et al. (1999).

\section{Chronology}

Three accelerator mass spectrometer (AMS) radiocarbon dates were obtained for this work by the AMS Laboratory of the University of Arizona, which were converted into calendar years using the calibration curves of Stuiver and Reimer (1993). The information about each sample, including radiocarbon years before present (RCYBP) and calibration ages, is listed in Table 1 (Irurzun et al., 2006).

Distinctive magnetic features of El Trébol D and I record, close to the dated levels, were identified and correlated with similar features of the PSV curves from Lake Escondido $\left(41^{\circ} \mathrm{S}, 71^{\circ} 30^{\prime} \mathrm{W}\right.$, Gogorza et al., 2002); so three connecting points were defined (Irurzun et al., 2006). This correlation was consistent with the age scale determined for Lake Escondido. The three connecting points define four zones; within each zone new tie points were determined (based on visual inspection of the curves). On the basis of this correlation, a total of 44 tie points were defined. Ages of the most distinctive declination peaks were transferred to the Lake El Trébol record and inclination features were matched. Minor changes in inclination and declination were then correlated (Irurzun et al., 2006). The lowest correlation point between Lake El Trébol and Lake Escondido was at a sediment depth of $710 \mathrm{~cm}$ in Lake El Trébol, which means a calibrated age of about 19,000 years. If the same sedimentation rate is assumed for the additional $140 \mathrm{~cm}$, the resulting basal age for the base of the profile of Lake El Trébol is ca. 21,000 calibrated years (Irurzun et al., 2006).

\section{Results \\ 6.1 Magnetic properties}

The first reliability tests for sedimentary paleointensity are the rock magnetic criteria suggested by Banerjee et al. (1981), King et al. (1982, 1983), Tauxe (1993). These are (1) the remanence must be carried by stable magnetite grains ranging in size from $1-15 \mu \mathrm{m}$, (2) the concentration may not vary by more than a factor of 10 , (3) the normalisation parameters must account for the variability in the contribution of the grain carrying the remanence (controlled largely by changes in concentration and grain size). Those samples that do not meet the criteria for magnetic uniformity have been omitted from our estimates of the relative paleointensity of the geomagnetic field (about 20\%). Rock magnetic measurements were performed on set of samples and some of the results are summarised in Fig. 2.

Thermal demagnetisation of SIRM shows no evidence for a contribution from minerals other than magnetite for samples of lithologies A-B (Fig. 2(a)). However, thermal demagnetisation of samples of lithology $\mathrm{C}$ indicates a con- 


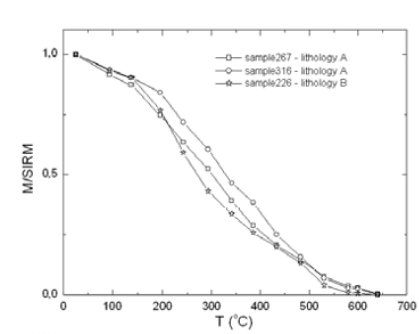

(a)
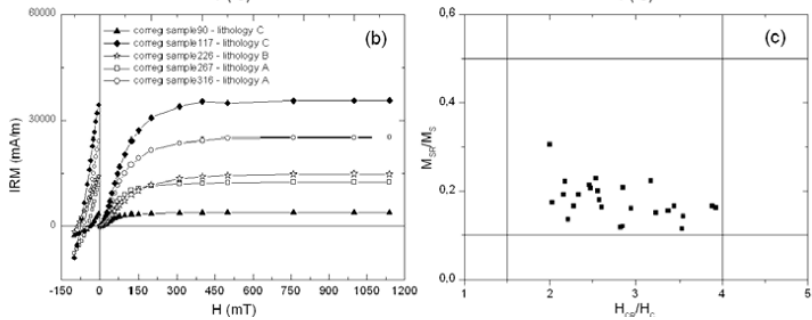

Fig. 2. (a) Thermal demagnetisation curves of SIRM for three samples from the lower part of the sequence and four from the upper one. (b) IRM acquisition curves of samples from different lithologies. (c) Hysteresis parameter ratios, $\mathrm{H}_{\mathrm{CR}} / \mathrm{H}_{\mathrm{C}}$ vs. MRS/MS for estimation of grain size.

centration of unblocking temperatures below $300^{\circ} \mathrm{C}$, implying the presence of more than one magnetic mineral (Fig. 2(a)). These results are indicative that magnetite is the dominant magnetic carrier of remanence in the cores, but the presence of a low proportion of titanomagnetite in the younger section cannot be excluded.

Stepwise acquisition of the isothermal remanence in fields up to $1.2 \mathrm{~T}$ shows that about $90 \%$ of the SIRM is acquired at an applied field between 200 and $300 \mathrm{mT}$. Progressive removal of this SIRM by back-field demagnetisation indicates remanence coercivity $\left(\mathrm{H}_{\mathrm{CR}}\right)$ between 40 and $80 \mathrm{mT}$ (Fig. 2(b)). These results indicate that magnetite is the dominant magnetic carrier of remanence in these samples. The studies reported in Irurzun et al. (2006) indicate that the cores are characterised by an S-ratio that varies between 81 and $99 \%$ (average $91 \pm 3 \%$ ) in lithology C (except two samples whose S-ratio values are 78 and $79 \%$, respectively) and that varies between 86 and $96 \%$ (average $92 \pm 2 \%$ ) in lithologies $\mathrm{A}$ and $\mathrm{B}$, indicating the predominance of low-coercivity minerals like (titano-) magnetite (Meynadier et al., 1992).

Grain size changes of magnetic minerals were examined by measuring ratios of both hysteretic and other magnetic parameters. Hysteresis parameters are useful for determining grain size and domain state of magnetite particle (Day et al., 1977). In Fig. 2(c) we summarize the hysteresis properties for the analysed specimens: saturation magnetisation (MS), saturation remanence (MSR also SIRM), coercive force $\left(\mathrm{H}_{\mathrm{C}}\right)$, and coercivity of remanence $\left(\mathrm{H}_{\mathrm{CR}}\right)$. The hysteresis ratios are consistent with a dominant low-coercivity ferrimagnetic component (most likely magnetite) that is of PSD range (Pseudo Single Domain) magnetic grain size.

A rather uniform grain size along the sequence is also confirmed by the down-core changes in the ratios $\mathrm{ARM}_{100 \mathrm{mT}} / k$ and $\mathrm{ARM}_{100 \mathrm{mT}} / \mathrm{SIRM}$; higher ratios indicate a smaller grain size and a higher proportion of singledomain (SD) grains (Hunt et al., 1995). In Fig. 3 it can be seen that the variation of $\mathrm{ARM}_{100 \mathrm{mT}} / k$ and $\mathrm{ARM}_{100 \mathrm{mT}} / \mathrm{SIRM}$ is about 3 .
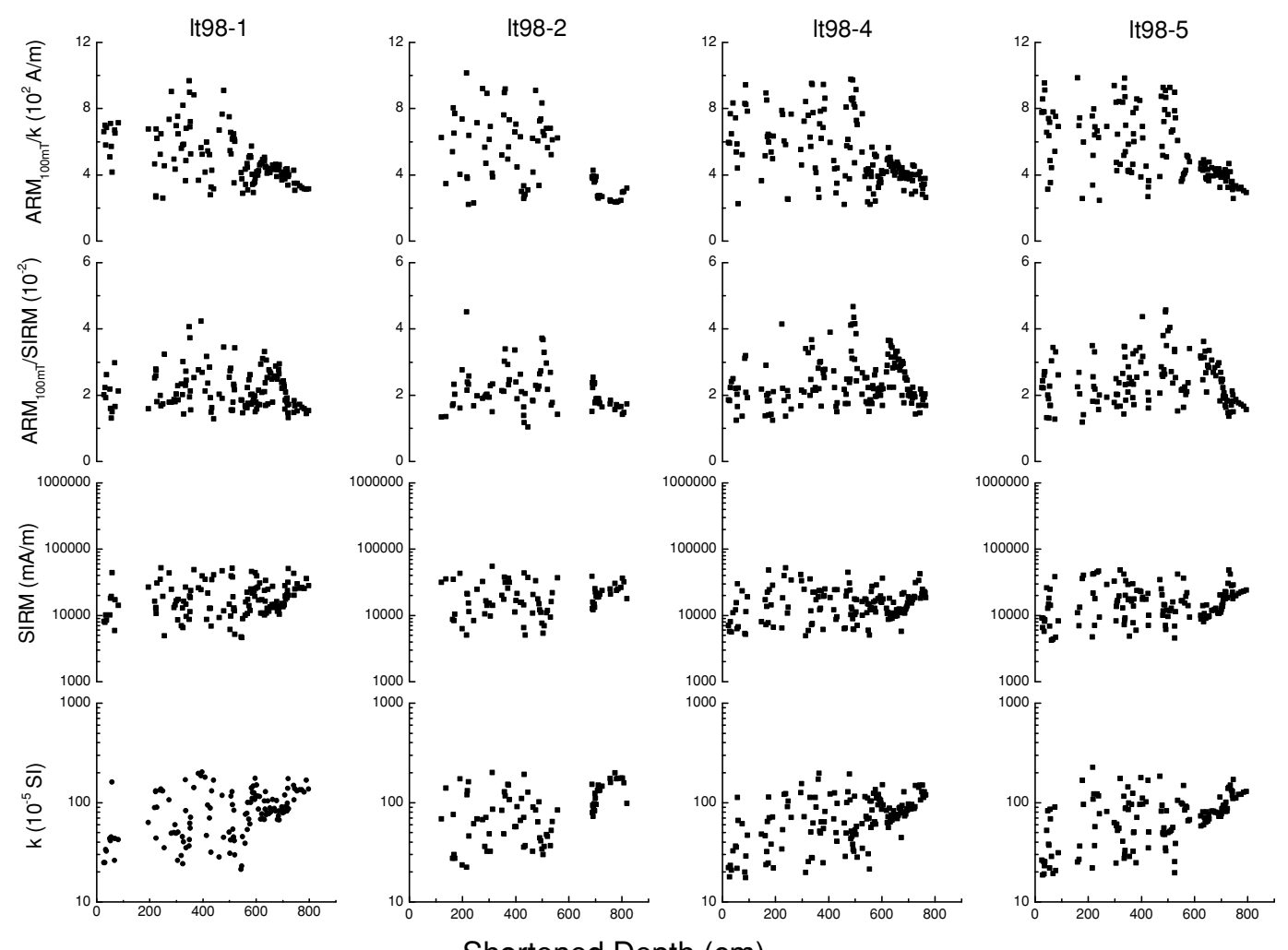

Shortened Depth (cm)

Fig. 3. $k$, SIRM, $\mathrm{ARM}_{100 \mathrm{mT}} / \mathrm{SIRM}$ and $\mathrm{ARM}_{100 \mathrm{mT}} / k$ records vs. shortened depth from cores 1t981, 1t98-2, 1t98-4 and lt98-5. 

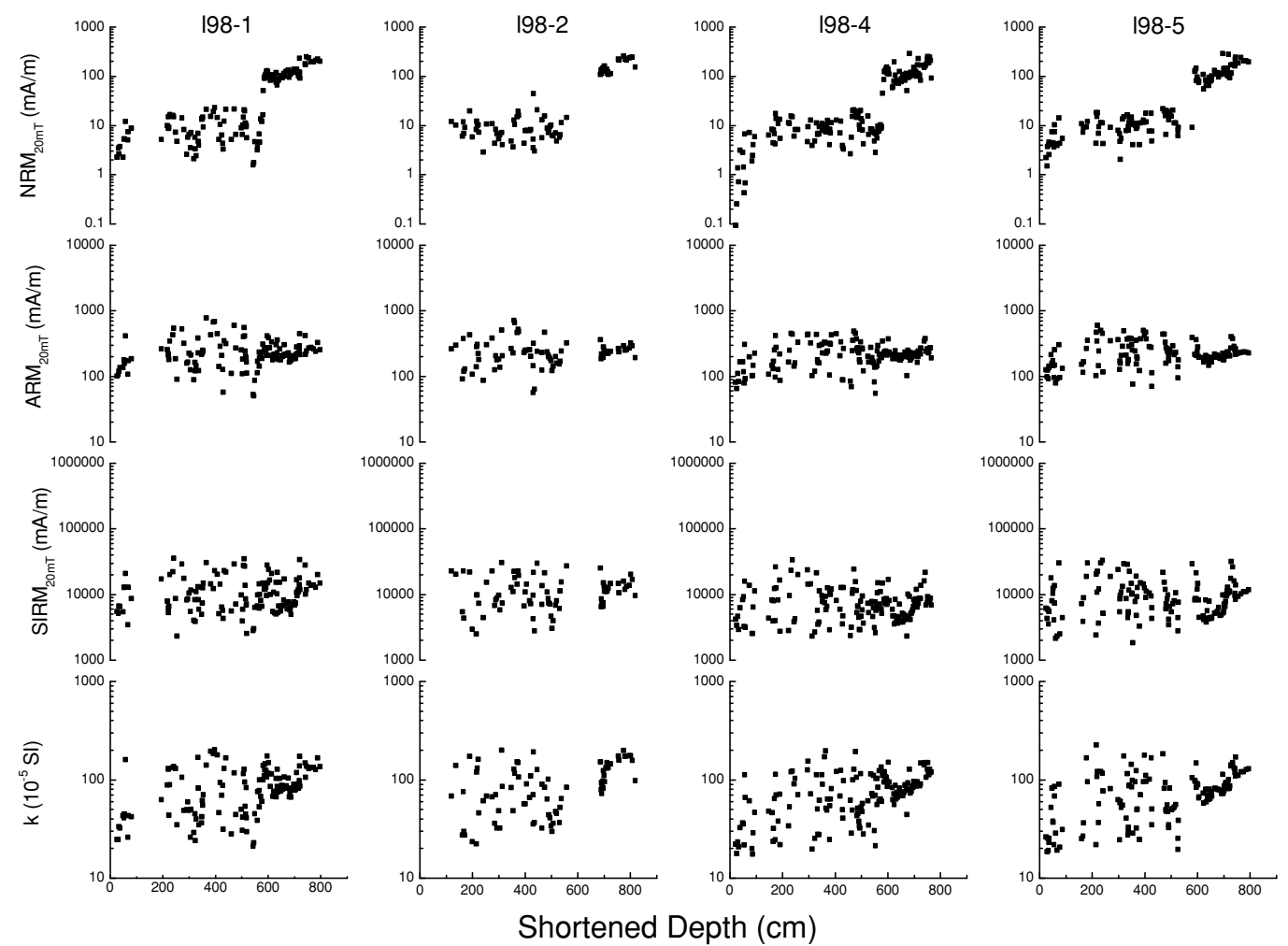

Fig. 4. $k, \mathrm{SIRM}_{20 \mathrm{mT}}, \mathrm{ARM}_{20 \mathrm{mT}}$ and $\mathrm{NRM}_{20 \mathrm{mT}}$ records vs. shortened depth from cores 1t981, 1t98-2, 1t98-4 and lt $98-5$.

The variation in the concentration of magnetic minerals can typically be monitored by the measurements of $k$ and SIRM. The latter is usually regarded as a better parameter to use for this purpose because it has no systematic grain dependence, while the former can be affected by superparamagnetic (SP) grains (Pan et al., 2001; Gogorza et al., 2004). Figure 3 shows that the ratio of the maximum to minimum value of $k$ and SIRM does not exceed a factor of about 10, proposed as an upper limit for relative paleointensity studies in sediments (Tauxe, 1993).

We conclude that the uniformity of rock magnetic results from these cores in terms of magnetic mineralogy, concentration and grain size is well within the criteria proposed for relative paleointensity studies (King et al., 1983; Tauxe, 1993).

\subsection{Directional records}

Lake El Trébol sediments record a stable, single component of remanence with an easily isolated characteristic component of remanence (Irurzun et al., 2006). Little viscous remanence is observed (Irurzun et al., 2006), and when present, it is generally removed by 10 or $15 \mathrm{mT}$ peak AF demagnetisation. Principal component analysis was carried out using four steps from 15-30 mT demagnetisation levels. The maximum angular deviations (MAD angles) are generally $<4.2^{\circ}$ in lithologies $\mathrm{A}$ and $\mathrm{B}$ and $<7.5^{\circ}$ in lithology C. Highest MAD angles (about $9.3^{\circ}$ ) were eliminated. These occur in the upper meter corresponding to spurious data at the top of the highly water saturated cores or they could clearly be attributed to artefacts at the top or bottom of some core sections (about $5 \%$ of the data). A univectorial characteristic remanence component is obtained by peak AFs of $20 \mathrm{mT}$ (Irurzun et al., 2006). Data at this de- magnetisation level were therefore used for paleointensity normalisation.

\subsection{Relative intensity estimates}

To obtain the paleointensity records, normalised remanence were generated using values of NRM, ARM and SIRM after AF demagnetisation at $20 \mathrm{mT}$. This peak is sufficient for complete removal of secondary components present in the NRM. The records of $\mathrm{NRM}_{20 \mathrm{mT}}, \mathrm{ARM}_{20 \mathrm{mT}}$, $\mathrm{SIRM}_{20 \mathrm{mT}}$ and $k$ are shown in Fig. 4 on a common depthscale for the four cores. There is good consistency between corresponding $\mathrm{ARM}_{20 \mathrm{mT}}, \mathrm{SIRM}_{20 \mathrm{mT}}$ and $k$, implying the $\mathrm{NRM}_{20 \mathrm{mT}}$ intensity is mostly modulated by changes in the geomagnetic field rather than by the environmental factors.

For each core, we have obtained three estimates of normalised field intensity using $\mathrm{ARM}_{20 \mathrm{mT}}, \mathrm{SIRM}_{20 \mathrm{mT}}$ and $k$ as normalising parameters. The results are shown in Fig. 5 on a common depth-scale for the four cores. The range of the changes is different in the upper ("Lake Trébol" facies) and lower section ("Lake Elpalafquen" facies); for this reason, the records are scaled by their respective mean values in order to be compared.

The consistency of the records from the different cores is a necessary consequence, but it also provides evidence that the sediments reliably record changes in the geomagnetic field intensity (Tauxe, 1993; Lehman et al., 1996).

Stacking provides a method for determining the "true" character of the record, as spurious features in individual records should be averaged out by the stacking process (Stoner et al., 2002). In order to yield the composite profile, the individual normalised paleointensity records were stacked. To perform this average, it is necessary to have data at the same depth for each core. For this reason, a lin- 


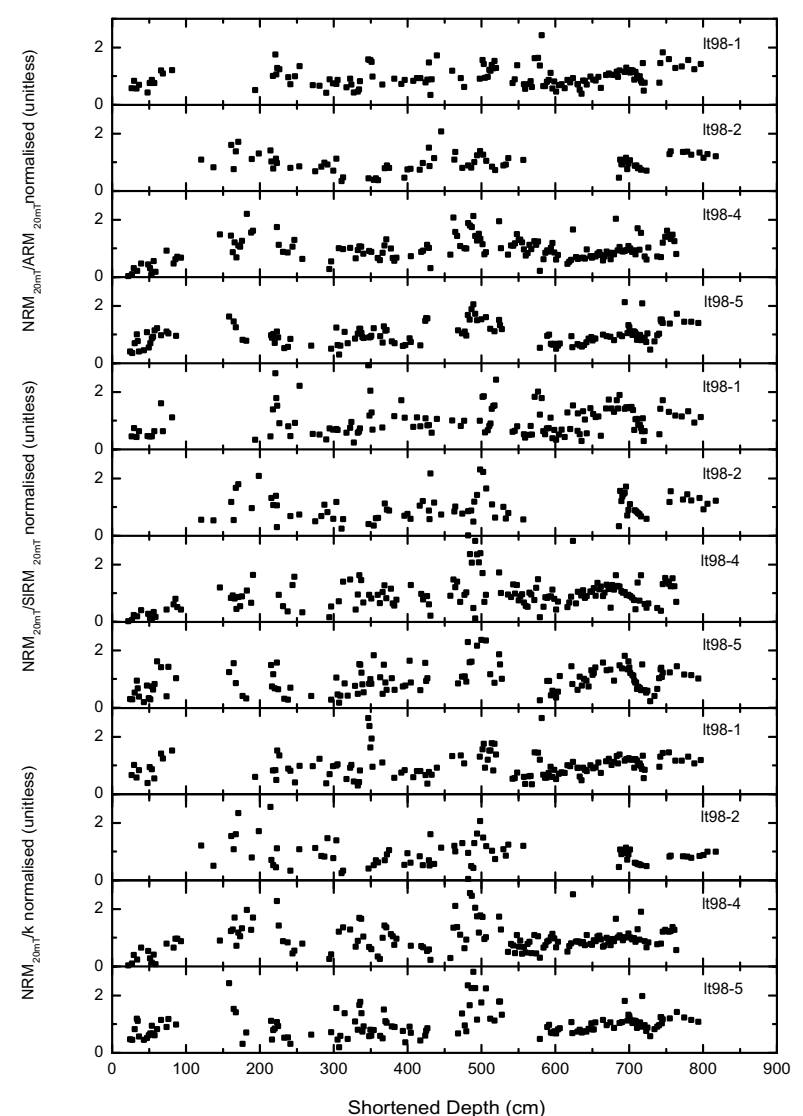

Fig. 5. Normalised $\mathrm{NRM}_{20 \mathrm{mT}} / k, \mathrm{NRM}_{20 \mathrm{mT}} / \mathrm{SIRM}_{20 \mathrm{mT}}$ and $\mathrm{NRM}_{20 \mathrm{mT}} /$ $\mathrm{ARM}_{20 \mathrm{mT}}$ records vs. shortened depth from cores lt98-1, 1t98-2, 1t98-4 and $1 \mathrm{t} 98-5$

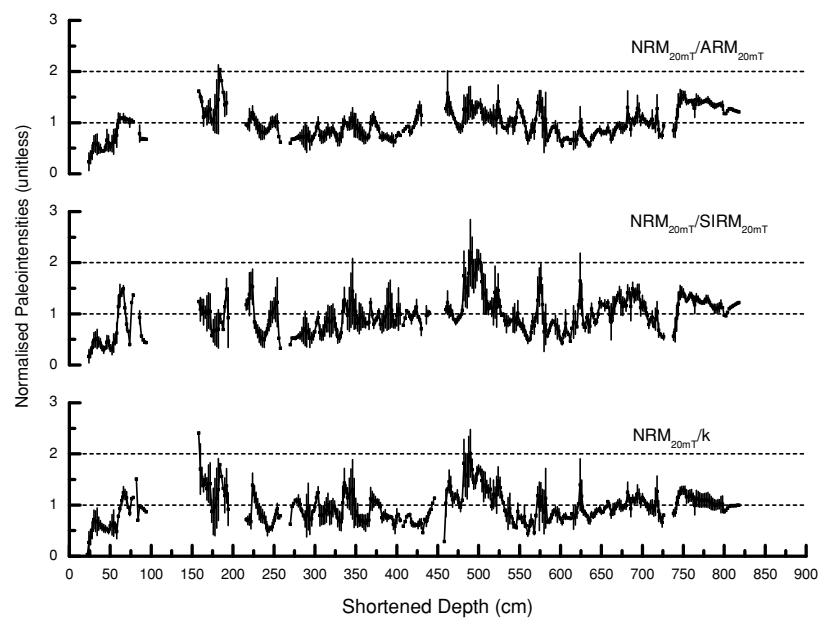

Fig. 6. Stacked $\mathrm{NRM}_{20 \mathrm{mT}} / \mathrm{ARM}_{20 \mathrm{mT}}, \mathrm{NRM}_{20 \mathrm{mT}} / \mathrm{SIRM}_{20 \mathrm{mT}}$ and $\mathrm{NRM}_{20 \mathrm{mT}} / k$ records vs. shortened depth.

eal interpolation was carried out, obtaining data every $2 \mathrm{~cm}$. The stack was then determined using the arithmetic mean at each interpolated sampling point and the $2 \sigma$ have been calculated for the error bars (Fig. 6).

Relative paleointensity profiles as a function of ${ }^{14} \mathrm{C}$ years B.P. using different normalisers are shown in Fig. 7.

\subsection{Coherence function analysis}

We carried out a coherence function analysis on the records to test the efficiency of the normalisations in re-

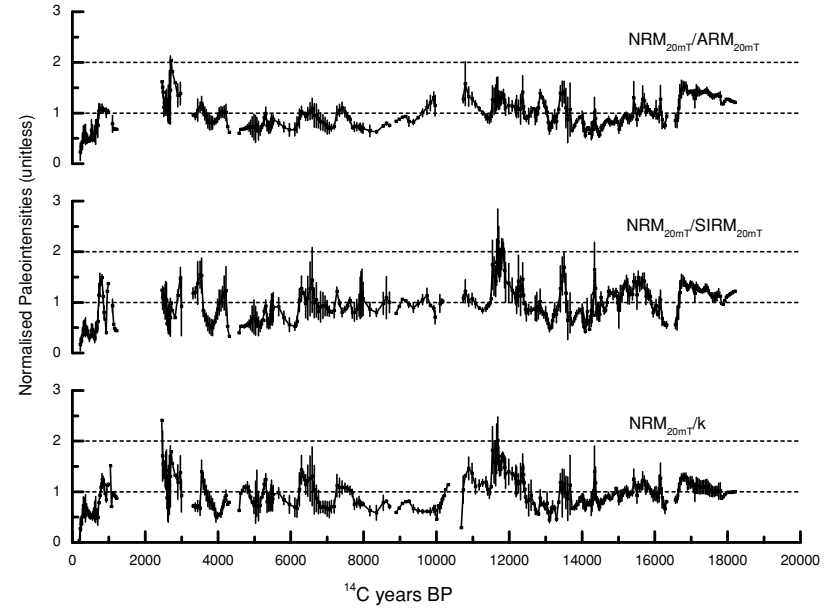

Fig. 7. Stacked $\mathrm{NRM}_{20 \mathrm{mT}} / \mathrm{ARM}_{20 \mathrm{mT}}, \mathrm{NRM}_{20 \mathrm{mT}} / \mathrm{SIRM}_{20 \mathrm{mT}}$ and $\mathrm{NRM}_{20 \mathrm{mT}} / k$ records vs. ${ }^{14} \mathrm{C}$ years BP.

moving the effects of climatic/environmental factors over specific frequency ranges. If the paleointensity record $\left(\mathrm{NRM}_{20 \mathrm{mT}} / \mathrm{ARM}_{20 \mathrm{mT}}\right.$, etc.) and the related normaliser $\left(\mathrm{ARM}_{20 \mathrm{mT}}\right.$, etc) do not show significant coherence, one may be confident that the paleointensity normalisation is not significantly affected by lithological or other environmental factors.

It is shown in Fig. 8 that at $95 \%$ confidence level $\mathrm{NRM}_{20 \mathrm{mT}} / \mathrm{SIRM}_{20 \mathrm{mT}}$ is coherent with its normaliser at some periods. It shows that we should not put too much faith in that normalisation. This behaviour is reduced to shorter periods by $k$ normalisation and missing by $\mathrm{ARM}_{20 \mathrm{mT}}$ normalisation. This analysis indicates that the parameter $\mathrm{ARM}_{20 \mathrm{mT}}$ is the more appropriate normaliser in these sediments (not coherent frequencies above the $95 \%$ confidence level) and that the $\mathrm{NRM}_{20 \mathrm{mT}} / \mathrm{ARM}_{20 \mathrm{mT}}$ record is not affected by climatic or lithologic factors but represents a true geomagnetic signal.

The spectral analysis of normalised remanences, normalisation parameters and coherence test (Fig. 8) were carried out following the method of Tauxe and Wu (1990) using MATLAB 6.1 software.

\section{Comparison with Other Records}

All of the above-described tests for assessing the reliability of relative paleointensity records are important; however, the most powerful test is whether there is agreement within the same geographic region, agreement between different depositional environments, and, ultimately, broad scale agreement between records from around the world (Roberts et al., 1997). The comparison of our normalised intensity record ( $\left.\mathrm{NRM}_{20 \mathrm{mT}} / \mathrm{ARM}_{20 \mathrm{mT}}\right)$ with existing paleointensity records may also provide information about the dipolar and no-dipolar nature of the main characteristics of the geomagnetic field during the studied period.

A comparison of $\mathrm{NRM}_{20 \mathrm{mT}} / \mathrm{ARM}_{20 \mathrm{mT}}$ with relative paleointensity records from the Southern and Northern Hemispheres is shown in Fig. 9(a)-(c). In Fig. 9(a) the comparison is restricted to records with radiocarbon chronologies: our records-the previous results from Lake Escondido 

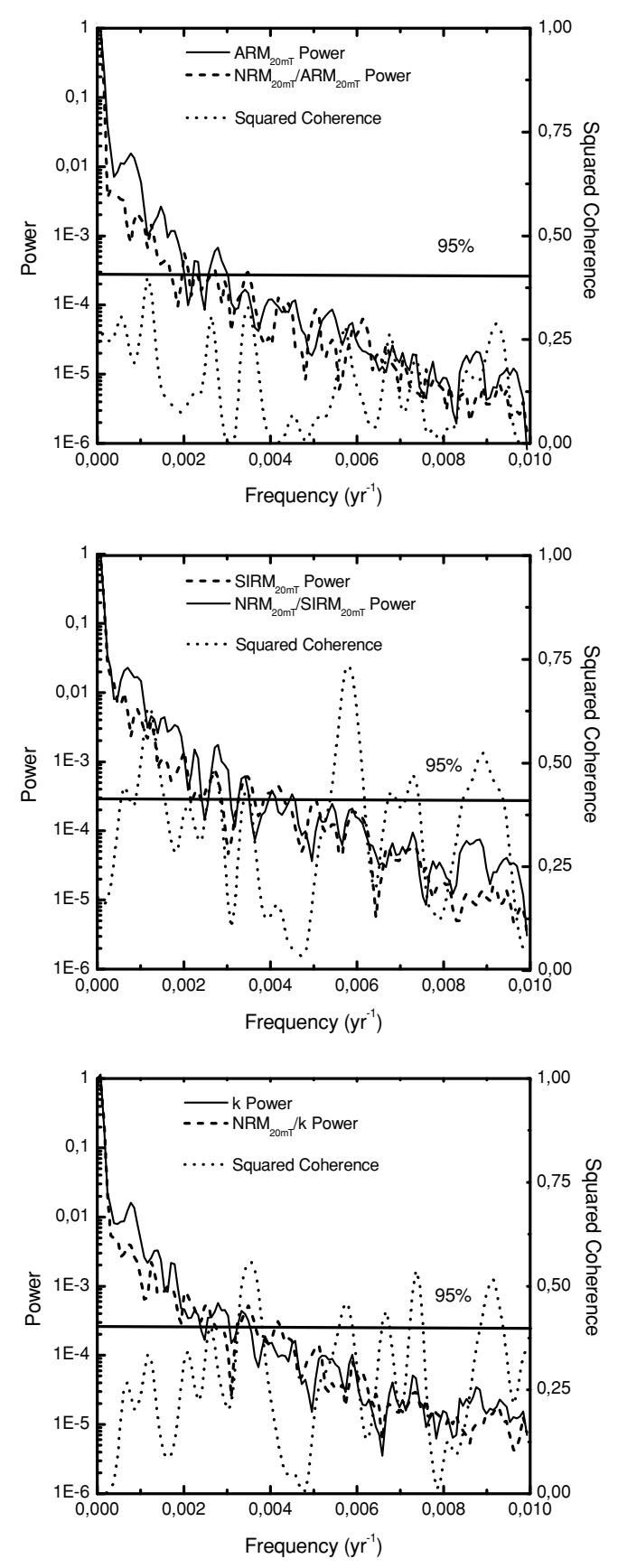

Fig. 8. Spectral analysis of three normalisation parameters $\left(\mathrm{ARM}_{20 \mathrm{mT}}, \mathrm{SIRM}_{20 \mathrm{mT}}\right.$ and $\left.k\right)$ and three normalised remanences $\left(\mathrm{NRM}_{20 \mathrm{mT}} / \mathrm{ARM}_{20 \mathrm{mT}}, \mathrm{NRM}_{20 \mathrm{mT}} / \mathrm{SIRM}_{20 \mathrm{mT}}\right.$ and $\left.\mathrm{NRM}_{20 \mathrm{mT}} / k\right)$. Coherence tests results are shown. The $95 \%$ confidence level is denoted by the horizontal line.

(Gogorza et al., 2004)—a sedimentary sequence collected from beneath the former Larsen-A Ice shelf, Antarctic Peninsula (Brachfeld et al., 2003); and the record of Lake Barrine (Constable, 1985) whose chronology is a hybrid ${ }^{14} \mathrm{C} / \mathrm{Calendar}$ Age. There is very good agreement between the records of the post-glacial section [0-10,000 RCYBP], displaying a high at about 2700 RCYBP in the Lake El Trébol and Larsen-A records, at about 2900 RCYBP in the Lake Escondido record and about 3280 RCYBP in the Lake Barrine record. Following this high, an oscillating be-

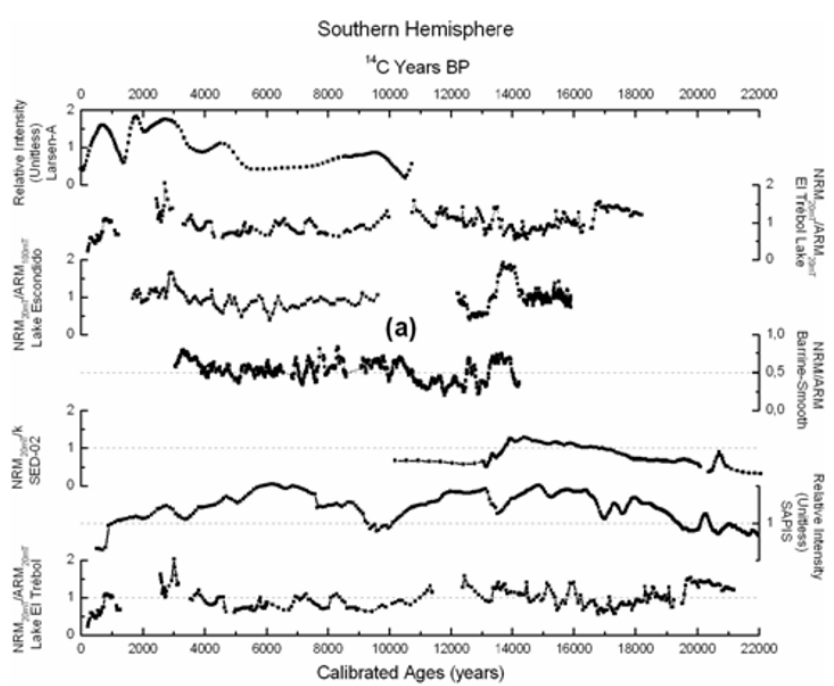

(b)

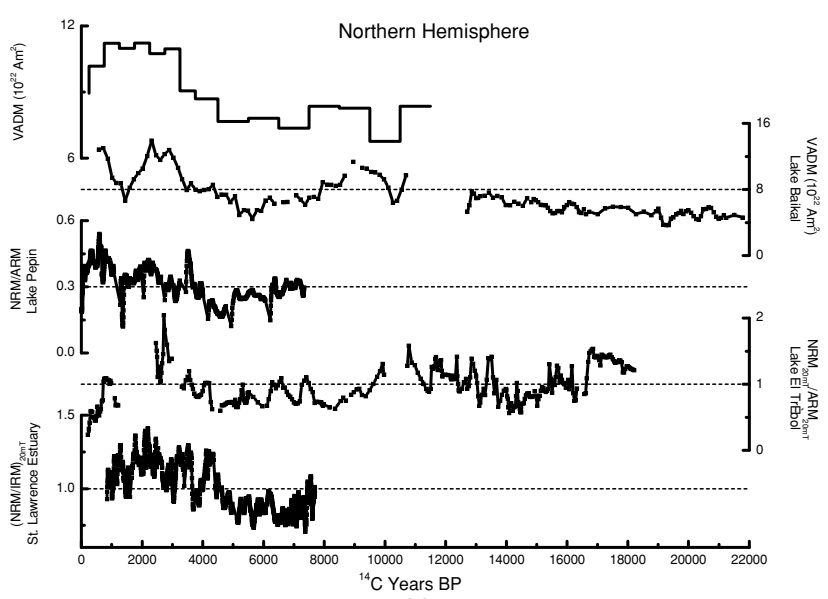

(c)

Fig. 9. Southern Hemisphere: (a) Comparison of normalised intensity record from the Lake El Trébol stack with relative paleointensity records from Larsen-A Ice Shelf and Lake Escondido in radiocarbon ages, (b) Lake Barrine, SEDANO-02 core and SAPIS stack in calibrated ages; Northern Hemisphere: (c) a global compilation of archeomagnetic data, Lake Baikal, Lake Pepin and St. Lawrence Estuary in radiocarbon ages.

haviour superimposed on a long trend below the mean between 3500 and about 10,000 RCYBP is observed. Both records, from Larsen-A and from Lake El Trébol, shows an increasing behaviour from about 200 RCYBP to about 750 RCYBP and a decreasing behaviour from this high to about 1200 RCYBP. A smoothing (running average of five points) was applied to the raw data recorded on Lake Barrine (figure 5(b) from Constable, 1985) to avoid abrupt variations in paleointensity records. Some of the discrepancies in timing between Lake Barrine and the other records could be due to inaccuracies in dating in the Australian records (Constable, 1985). Lake El Trébol and Lake Barrine show some similarities: both records exhibit a decreasing behaviour between 10700 to 11300 RCYBP (actually Lake Barrine shows this behaviour since 10300 RCYBP but it is not possible to compare this with Lake El Trébol because there is a gap at this age). Finally, a notorious high observed — at about 13500 RCYBP - in the Lake Escondido record is not exactly coincident, neither in time nor in amplitude, with the peak ob- 
served at about 13450 RCYBP in Lake El Trébol and Lake Barrine. For this reason, we have doubts that they are reflecting the same feature.

Figure 9(b) shows our present record, the results from South Atlantic geomagnetic paleointensity stack, SAPIS (Stoner et al., 2002) and one of the three cores (SEDANO) collected from Antarctic late Pleistocene sediments (Sagnotti et al., 2001). In these cases, relative paleointensities are represented against calibrated ages. We must take care when dealing with the pre-glacial section. As was emphasized in Gogorza et al. (2004), the normalised remanence records in the 0-20,000 years of the SAPIS stack (Stoner et al., 2002) should be viewed with caution, because of the perturbation induced by the presence of ultra-fine magnetite in the upper part of some of the cores used for the stacking process. This could explain misalignment between paleointensity features in our record and the results from SAPIS, although a clear low in the interval 8600-11,300 years is shown in SAPIS and in the Lake El Trébol records. All the records contain a 13,200 and 19,400 years low and the 19,800 high, although these features are not exactly coincident neither in time nor in amplitude. Further studies would be necessary to draw a reasonable conclusion about the pre-glacial paleointensities from lakes of South Argentina (Gogorza et al., 2004).

Figure 9(c) shows the comparison of our record with the relative paleointensity from Lake Pepin (Brachfeld and Banerjee, 2000), St. Lawrence Estuary (St-Onge et al., 2003), Lake Baikal (Peck et al., 1996) and a compilation of archeomagnetic data (Yang et al., 2000). The agreement between the paleointensity records presented is quite good, especially for the time interval 200-10,000 RCYBP. The distinct long trend between $\sim 3000$ and 10,000 RCYBP could clearly be identified in all records, which is consistent with the global absolute paleointensity results derived from archaeological material (Yang et al., 2000). Comments similar to those presented in Gogorza et al. (2004) about the surprising agreement observed between the records from lakes that are thousands of kilometres away, may be carried out in this work. In the time interval 10,700-21,000 RCYBP, inter-lake comparison of the records is difficult; the similarities are limited. The reasons for this difference are not clear. The more notorious characteristic is, in general, a long trend decrease in the Lake El Trébol record that is matched by a long trend decrease in the Lake Baikal record. However, there are sub-millennial features that are not found in both records.

\section{Discussion}

There is a clear difference in the behaviour of the inter-parametric ratios $\mathrm{ARM}_{100 \mathrm{mT}} / \mathrm{SIRM}$ and $\mathrm{ARM}_{100 \mathrm{mT}} / k$ (Fig. 3) between both the El Trébol and Elpalafquen facies. The behaviour observed in Fig. 3 suggests that the magnetic grain size was coarser in sediments from Elpalafquen facies than sediments from Lake El Trébol facies (Gogorza et al., 2004; Irurzun et al., 2006). The changes of behaviour of the studied parameters coincide with the end of the transition from the last glaciation of the Holocene, as indicated by the refinement of bulk sediment particle size above this boundary. The observed shift from coarser to finer PSD magnetite therefore could be the result of a major change in sedimentology, indicating a change in the source of relative flux-density of detrital input from different sources to the site of deposition (Nowaczyk et al., 2001).

The magnetic parameters (SIRM and $k$; Fig. 3) show strong variations with a lot of spikes in the upper section of the sequence; while the lower part appears much smoother with comparatively little variations, indicating a rather monotonous sedimentation, but, the mean values are similar for both facies (Gogorza et al., 2004). This behaviour could be explained by a heterogeneous sediment composition in the upper part which arises from larger environmental changes.

The observed down-core trend in $\mathrm{NRM}_{20 \mathrm{mT}}$ (Fig. 4) is an indicator of significant variations between the upper and lower parts of the sequence. This is probably a consequence of a combination of factors like differences in concentration of magnetite and less efficient recording due to grain size and/or lithology effects (Gogorza et al., 2004). The apparent decrease in the minerogenic content of the sediments, reflected by a decrease in $\mathrm{NRM}_{20} \mathrm{mT}$ and an increase in water content, could be attributed to a slow retreat of the glaciers from the lake catchment during the Late Glacial, also resulting in a decrease in grain size (Frank et al., 2002). Warming up causes retirement of glaciers and an increase of the melt water stream, then there is decreasing of suspended sediment concentration and therefore, a decrease in the magnetic mineral content (Harwart et al., 1999).

The paleointensity proxy of choice is generally either NRM/IRM or NRM/ARM. Both remanences in the ratios are measured after demagnetisation at a particular peak AF in order to eliminate viscous or other low-coercivity contributions to remanence. The normaliser (IRM or ARM) should activate the same grain population as that which carries the NRM. The objective is to compensate for changes in concentration of remanence carrying grains (Channell, 1999). Volume (low field) susceptibility $k$ is occasionally used as the normaliser. However, large multidomain magnetic grains (and paramagnetic and superparamagnetic grains), which could be important contributors to susceptibility, would not be important contributors to the remanence. Susceptibility is therefore not usually the preferred normaliser (Channel et al., 1999).

Although the three methods of normalisation yield essentially the same intensity records, we have chosen $\mathrm{ARM}_{20} \mathrm{mT}$ as the preferred normaliser based on the results of coherence function analysis: lack of coherence between the normalised remanence and bulk mineral magnetic parameters provide the evidence that the paleointensity normalisation $\left(\mathrm{NRM}_{20 \mathrm{mT}} / \mathrm{ARM}_{20 \mathrm{mT}}\right)$ is not affected by lithological or other environmental factors. Moreover, ARM is preferred because it is similar to thermal remanence which is the presumed origin of remanence in detrital grains (Levi and Banerjee, 1976; Tauxe and $\mathrm{Wu}, 1990)$.

When we compare our record with marine cores -SED02 (Sagnotti et al., 2001) and SAPIS (Stoner et al., 2002)-, we have to face the problem of different methods of dating (Lehman et al., 1996). The lacustrine sections are usually characterised by larger sedimentation rates, improving the time resolution of the record. However, in most cases, tem- 
poral changes in the magnetic mineralogy and granulometry are greater than in the best marine cores (Lehman et al., 1996). It is difficult to determine whether the differences observed between the records within the interval 13,00020,000 years in Lake El Trébol, came from an incorrect time correlation or from different rock magnetic characteristics. Difficulties also arise for the high-frequency part of the record, because short-lived intensity fluctuations may have been recorded with different resolutions between records, precluding their unambiguous recognition (Lehman et al., 1996). In general, our records and the marine records studied show similar trends, although it is not possible to obtain a close correlation among them. For this reason, it would be necessary to carry out more comparative analysis to reach a convincing conclusion.

In summary, broad-scale similarities between the timing of the features in the various records are encouraging and suggest that a predominantly global signal is recorded by Lake El Trébol sediments (Roberts et al., 1997; Valet, 2003).

\section{Conclusions}

The composite $\mathrm{NRM}_{20 \mathrm{mT}} / \mathrm{ARM}_{20 \mathrm{mT}}$ curve represents an estimate of geomagnetic paleointensity variations in SouthWestern Argentina. The obtained records meet the strictest criteria for relative paleointensity records: the most commonly applied mineral magnetic criteria, paleomagnetic stability, agreement between results of different paleomagnetic normalisation and agreement with records obtained from other geographical areas. The dominant remanence carrier is magnetite and titano-magnetite within the pseudosingle domain (PSD) grain size and the concentration of these minerals change in a factor of ten.

From the comparison of the relative paleointensity records was observed that the (millennial-scale) longer wavelength $\left(\sim 10^{3}-10^{4}\right.$ year) features can be correlated over many thousands of kilometres suggesting that the longer period content is controlled by the global-scale geomagnetic field.

Acknowledgments. The authors wish to thank Universidad Nacional del Centro de la Provincia de Buenos Aires (UNCPBA), Instituto Antártico Argentino (IAA), Consejo Nacional de Investigaciones Científicas y Técnicas de la República Argentina (CONICET), Third World Academy of Sciences (TWAS) and Universidad de Buenos Aires (UBA). They are indebted to Martín Santiago and J. F. Vilas for their help on the field. They wish to thank sincerely S. Brachfeld, J. Peck, J. Stoner, G. St-Onge, L. Sagnotti and C. Constable for generously sharing their data. The authors are also indebted to the anonymous reviewers for their useful suggestions.

\section{References}

Banerjee, S. K., J. King, and J. Marvin, A rapid method for magnetic granulometry with applications to environmental studies, Geophys. Res. Lett., 8, 333-336, 1981.

Bianchi, M. M., J. Masaferro, G. Roman Ross, A. J. Amos, and A. Lami, Late Pleistocene and early Holocene ecological response of Lake El Trébol (Patagonia, Argentina) to environmental changes, J. Paleolimnology, 22, 137-148, 1999.

Brachfeld, S. A. and S. A. Banerjee, A new high-resolution geomagnetic relative paleointensity record for the North American Holocene: A comparison of sedimentary and absolute intensity data, J. Geophys. Res., 105, B1, 821-834, 2000.
Brachfeld, S. A., E. Domack, C. Kisel, C. Laj, A. Leventer, S. Ishman, R. Gilbert, A. Camerlenghi, and L. B. Eglinton, Holocene history of the Larsen-A Ice Shelf constrained by geomagnetic paleointensity dating, Geology, 31(9), 749-752, 2003.

Channell, J. E. T., Geomagnetic paleointensity and directional secular variation at Ocean Drilling Program (ODP) Site 984 (Bjorn Drift) since 500 ka: Comparisons with ODP Site 983 (Gardar Drift), J. Geophys. Res., 104(B10), 22,937-22,951, 1999.

Channell, J. E. T., J. S. Stoner, D. A. Hodell, and C. D. Charles, Geomagnetic paleointensity for the last $100 \mathrm{kyr}$ from the sub-Antartic South Atlantic: A tool for inter-hemispheric correlation, Earth Planet. Sci. Lett., 175(1-2), 145-160, 2000.

Constable, C. G., Eastern Australian geomagnetic field intensity over the last 14000 yr., Geophys. J. Res, 81, 121-130, 1985.

Day, R. M., D. Fuller, and V. A. Schmidt, Hysteresis properties of titanomagnetite: Grain size and composition dependence, Phys. Earth Planet. Inter., 13, 260-266, 1977.

del Valle, R. A., J. M. Lirio, H. J. Nunez, A. Tatur, and C. A. Rinaldi, J. C. Lusky, and A. J. Amos, Reconstrucción paleoambiental PleistocenoHoloceno en latitudes medias al E. de los Andes, Actas XIII Congreso Geológico Argentino, 4, 85-102, 1996.

del Valle, R. A., J. M. Lirio, H. J. Nunez, A. Tatur, and C. A. Rinaldi, Sedimentary cores from Mascardi Lake, Argentina: a key site to study Elpalafquen paleolake, in Southern Hemisphere Paleo and Neoclimates, edited by P. Smolka and W. Volkheimer, 381 pp., Springer Verlag, Heidelburg, 2000.

Flint, R. F. and F. Fidalgo, Glacial Geology of the east flank of the Argentine Andes between Lat. $41^{\circ} 10^{\prime}$ and Lat. $43^{\circ} 10^{\prime} \mathrm{S}$, Geolog. Soc. Am. Bull., 75, 335-352, 1964.

Flint, R. F. and F. Fidalgo, Glacial drift in the Eastern Argentine Andes between Lat. $41^{\circ} 10^{\prime}$ and Lat. $43^{\circ} 10^{\prime}$ S, Geolog. Soc. Am. Bull., 80, 1043-1052, 1969.

Frank, U., N. R. Nowaczyk, J. F. W. Negendank, and M. Melles, A paleomagnetic record from Lake Lama, northern Central Siberia, Phys. Earth and Planet. Inter., 133, 3-20, 2002.

Gogorza, C. S. G., A. M. Sinito, I. Di Tomasso, J. F. Vilas, K. M. Creer, and H. Nunez, Holocene Secular variation recorded by sediments from Lake Escondido (South Argentina), Earth Planets Space, 51, 93-106, 1999.

Gogorza, C. S. G., A. M. Sinito, I. Di Tomasso, J. F. Vilas, K. M. Creer, and H. Nunez, Geomagnetic Secular Variations 0-12000 yr. as recorded by sediments from Moreno Lake (South Argentina), J. South American Earth Sci., 13, 7, 627-645, 2001.

Gogorza, C. S. G., A. M. Sinito, J. M. Lirio, H. Nunez, M. A. E. Chaparro and J. F. Vilas, Paleosecular Variations 0-19,000 years recorded by sediments from Escondido Lake (Argentina), Phys. Earth and Planet. Inter., 133, 35-55, 2002.

Gogorza, C. S. G., J. M. Lirio, H. Nunez, M. A. E. Chaparro, H. R. Bertorello, and A. M. Sinito, Paleointensity studies on HolocenePleistocene sediments from Lake Escondido, Argentina, Phys. Earth and Planet. Inter., 145, 219-238, 2004.

Harwart, S., B. Hagedorn, M. Melles, and U. Wand, Lithological and biochemical properties in sediments of Lama Lake as indicators for the late Pleistocene and Holocene ecosystem development of the southern Taymyr Peninsula, Central Siberia, Boreas, 28, 167-180, 1999.

Hunt, C. P., S. K. Banerjee, J. Han, P. A. Solheid, E. Oches, W. Sun, and T. Liu, Rock-magnetic proxies of climate change in the loess-paleosol sequences of the western Loess Plateau of China, Geophys. J. Int., 123, 232-244, 1995.

Irurzun, M. A., C. S. G. Gogorza, A. M. Sinito, J. M. Lirio, H. Nunez, and M. A. E. Chaparro, Paleosecular variations recorded by sediments from Lake El Trébol, Argentina, Phys. Earth and Planet. Inter., 154, 1-17, 2006.

King, J., S. K. Banerjee, J. Marvin, and Ö. Özdemir, A comparison of different magnetic methods for determining the relative grain size of magnetite in natural materials: Some results from lake sediments, Earth Planet. Sci. Lett., 59, 404-419, 1982.

King, J. W., S. K. Banerjee, and J. Marvin, A new rock magnetic approach to selecting sediments for geomagnetic paleointensity studies: Application to paleointensity for the last 4000 years, J. Geophys. Res., 88 , 5911-5921, 1983.

Kruiver, P. P., Y. S. Kok, M. J. Dekkers, C. G. Langereis, and C. Laj, A pseudo-Thellier relative paleointensity record, and rock magnetic and geochemical parameters in relation to climate during the last $276 \mathrm{kyr}$. in the Azores region, Geophys. J. Int., 136, 757-770, 1999. 
Laj, C., C. Kissel, A. Mazaud, J. E. T. Channell, and J. Beer, North Atlantic palaeointensity stack since $75 \mathrm{ka}$ (NAPIS-75) and the duration of the Laschamp event, Philos. Trans. R. Soc. London, Ser. A, 358, 10091025, 2000.

Lehman, B., C. Laj, C. Kissel, A. Mazaud, M. Paterne and L. Labeyrie, Relative changes of the geomagnetic field intensity during the last 280 kyear from piston cores in the Azores area, Phys. Earth Planet. Inter. 93, 269-284, 1996.

Levi, S. and S. K. Banerjee, On the possibility of obtaining relative paleointensities from lake sediments, Earth Planet. Sci. Lett., 29, 219-226, 1976.

Meynadier, L., J. P. Valet, R. Weeks, N. J. Shackleton, and V. L. Hagee, Relative geomagnetic intensity of the field during the last $140 \mathrm{ka}$, Earth Planet. Sci. Lett., 114, 39-57, 1992.

Nowaczyk, N. R., S. Harwart, and M. Melles, Impact of early diagenesis and bulk particle grain size distribution on estimates of relative geomagnetic palaeointensity variations in sediments from Lama Lake, northern Central Siberia, Geophys. J. Int., 145, 300-306, 2001.

Pan, Y., R. Zhu, J. Shaw, Q. Liu, and B. Guo, Can relative paleointensities be determined from the normalised magnetisation of the wind-blown loess of China?, J. Geophys. Res., 106(B9), 19,221-19,232, 2001.

Peck, J. A., J. W. King, S. M. Colman, and V. A. Kravchinsky, An 84kyr. paleomagnetic record from the sediments of Lake Baikal, Siberia, J. Geophys. Res., 101(B5), 11,365-11,385, 1996.

Peng, L. and J. W. King, A late Quaternary geomagnetic secular variation record from Lake Waiau, Hawaii, and the Question of the Pacific nondipole low, J. Geophys. Res., 97(B4), 4,407-4,424, 1992.

Rabassa, J. and Ch. Clapperton, Quaternary glaciations of the Southern Andes, Quat. Sci.Rev., 9, 153-174, 1990.

Roberts, A. P., B. Lehman, R. Weeks, K. Verosub, and C. Laj, Relative paleointensity of the geomagnetic field over the last 200,000 years from ODP Sites 883 and 884, North Pacific Ocean, Earth Planet. Sci. Lett., 152, 11-23, 1997.

Sagnotti, L., P. Macri, A. Camerlenghi, and M. Rebesco, Environmen- tal magnetism of Antarctic Late Pleistocene sediments and interhemispheric correlation of climatic events, Earth Planet. Sci. Lett., 192, 6580, 2001.

Sinito, A. M. and H. J. Nunez, Paleosecular variation recorded on lake sediments from South Argentina, J. Geomag. Geoelectr., 49, 473-483, 1997.

Stoner, J. S., C. Laj, J. E. T. Channell, and C. Kissel, South Atlantic and North Atlantic geomagnetic paleointensity stacks $(0-80 \mathrm{ka})$ : implications for inter-hemispheric correlation, Quat. Sci. Rev., 21, 1141-1151, 2002.

St-Onge, G., J. S. Stoner, and C. Hillaire-Marcel, Holocene paleomagnetic records from St. Lawrence Estuary, eastern Canada: centennialto millennial-scale geomagnetic modulation of cosmogenic isotopes, Earth Planet. Sci. Lett., 209, 113-130, 2003.

Stuiver, M. and P. J. Reimer, Extended ${ }^{14} \mathrm{C}$ data base and revised Calib 3.0 ${ }^{14} \mathrm{C}$ age calibration program, Radiocarbon, 35, 215-230, 1993.

Tauxe, L., Sedimentary records of relative paleointensities of the geomagnetic field: theory and practice, Rev. Geophys., 31, 319-354, 1993.

Tauxe, L. and G. Wu, Normalised remanence in sediments of the western equatorial Pacific: Relatively intensity of the geomagnetic field?, $J$. Geophys. Res., 95, 12,337-12,350, 1990.

Tric, E., J. P. Valet, P. Tucholka, M. Paterne, L. LaBeyric, F. Guichard, L. Tauxe, and M. Fontugne, Paleointensity of the geomagnetic field during the last 80,000 years, J. Geophys. Res., 97, 9,337-9,351, 1992.

Valet, J. P., Time variations in geomagnetic intensity, Rev. Geophys., 41, 4,1-4,44, 2003.

Yang, S., H. Odah, and J. Shaw, Variations in the geomagnetic dipole moment over the last 12,000 years, Geophys. J. Int., 140, 158-162, 2000.

C. S. G. Gogorza (e-mail: cgogorza@exa.unicen.edu.ar), M. A Irurzun, M. A. E. Chaparro, J. M. Lirio, H. Nunez, P. G. Bercoff, and A. M. Sinito 